\title{
Pengaruh Lembar Kerja Peserta Didik (LKPD) Terhadap Hasil Belajar IPS Siswa Kelas IV SD YPK Getsemani Warwanai
}

\author{
Mursalim $^{1}$ \& Tabita Adonia Rumbarak ${ }^{2}$
}

Prodi PGSD, Universitas Pendidikan Muhammadiyah Sorong, Indonesia

${ }^{\bowtie}$ E-mail: mursalim47@gmail.com

\begin{abstract}
Abstrak
Penelitian ini bertujuan untuk mengetahui pengaruh lembar kerja peserta didik terhadap hasil belajar siswa kelas IV SD YPK Getsemani Warwanai. Penelitian ini merupakan penelitian pre-exsperimental design dengan desain penelitian nonequivalent control group design. Populasi dalam penelitian ini adalah seluruh siswa kelas IV SD YPK Getsemani Warwanai berjumlah 22, sedangkan sampel penelitian adalah kelas IVa dengan jumlah siswa 11. Pengambilan sampel menggunakan sampling jenuh. Pengumpulan data menggunakan metode observasi dan tes hasil belajar. Analisis data menggunakan uji normalitas, homogenitas, N-Gain, dan uji hipotesis. Hasil penelitian ini menunjukkan bahwa rata-rata belajar kelas eksperimen 89,09 dan kelas kelas kontrol 57,73, dan nilai $\mathrm{t}_{\text {hitung }}$ sebesar 14,644 dengan signifikansi 0,000. Hasil uji paired $t$-test dari data kelas kontrol diperoleh nilai $t_{\text {hitung }}>t_{\text {tabel }}(11,066>2,228)$, nilai kelompok eksperimen yaitu $t_{\text {hitung }}>t_{\text {tabel }}(14,644>2,228)$. Namun $t_{\text {hitung }}$ pada kelompok eksperimen lebih besar dari $t_{\text {hitung }}$ kelompok kontrol dengan besar taraf Sig (2tailed) $0,000<0,05$ sehingga dapat $\mathrm{H}_{1}$ diterima dan $\mathrm{H}_{0}$ ditolak. Artinya dari perhitungan analisis data tersebut dapat disimpulkan bahwa terdapat pengaruh lembar kerja peserta didik (LKPD) terhadap hasil belajar siswa kelas IV SD YPK Getsemani Warwanai.
\end{abstract}

Kata Kunci: Lembar Kerja Peserta Didik (LKPD); Hasil Belajar; IPS.

\begin{abstract}
The study is intended to know the impact of the learner's worksheet on the study of the fourth class class ypk gethsemane warwanai. This research is a pre-experimental design with a noninvasive control group design. The population in the study is all the fourth graders of the ypk gethsemane warwanai numbered 22, while the study sample is the iva class with the number of 11 students. Sampling samples are using the saturated samples. Data collection USES observation and testing methods of learning. Data analysis USES normality tests, homosexuality, n-gains, and hypothetical tests. The findings suggest that the average study experimental class 89.09 and control class 57.73, and the value of 14.644 with 0,000 significance. Test results from the control class data acquired a thitung > ttables $(11,066>2.228)$, the value of the experiment group thitung > ttable $(14644>2.228)$. But thitung in experiment groups is larger than thitung control groups with great sig (2-tailed) $0,000<$ 0.05 so that $H_{1}$ is accepted and $H_{0}$ is rejected. The meaning of the data analysis suggests that there is an influence on LKPD on the study of the fourth class is the ypk gethsemane warwanai.
\end{abstract}

Keywords: Lembar Kerja Peserta Didik (LKPD); Learning Outcome; IPS. 


\section{PENDAHULUAN}

Pendidikan

pada hakikatnya merupakan suatu proses dalam rangka mempengaruhi peserta didik agar dapat menyesuaikan diri sebaik mungkin dengan lingkungannya. Pendidikan juga merupakan salah satu usaha yang mengupayakan untuk menyiapkan peserta didik melalui kegiatan bimbingan, pengajaran atau latihan bagi peranannya dimasa yang akan datang (Dian Vita Sari, 2019). Melalui jalur pendidikan pula peserta didik dibentuk menjadi pribadi yang tangguh, kreatif, mandiri, dan profesional pada bidangnya masing-masing kelak dimasa yang akan datang. Dalam meningkatkan kualitas sumber daya manusia, pendidikan memegang peran yang sangat penting. Dalam proses pendidikan tidak terlepas dengan yang namanya pendidik. Pendidik tersebut adalah seorang guru, dalam hal ini, guru yang menginformasikan materi kepada siswa, tentu saja dengan pembelajaran yang bersifat menarik agar mempengaruhi hasil belajar siswa. Dalam hal ini seorang guru menginformasikan materi pembelajaran kepada peserta didik melalui RPP, materi pembelajaran, media pembelajaran dan LKPD.

Untuk mencapai tujuan tersebut tidak terlepas dengan adanya lembar kerja peserta didik (LKPD). Penggunaan bahan ajar yang berupa lembar kerja peserta didik yang tepat akan membantu peserta didik dalam mengerjakan tugas baik secara mandiri maupun kelompok, memahami pelajaran dan menunjang pendidik dalam menerapkan proses belajar mengajar. Bahan ajar berupa LKPD merupakan salah satu sumber belajar yang dikembangkan oleh pendidik dalam kegiatan yang disusun dan dirancang sesuai dengan kondisi dan situasi kegiatan yang dihadapi, dimana berisi petunjuk dalam praktek, percobaan yang bisa dilakukan di rumah, materi untuk diskusi dan soal latihan dengan petunjuk agar peserta didik lebih aktif dalam proses pembelajaran (Dian Vita Sari, 2019). Lembar kerja peserta didik (LKPD) merupakan salah satu sarana untuk membantu dan mempermudah dalam kegiatan belajar mengajar sehingga akan terbentuk interaksi yang efektif antara peserta didik dengan pendidik, sehingga dapat meningkatkan aktivitas peserta didik dalam peningkatan prestasi belajar, LKPD yang disusun dapat dirancang dan dikembangkan sesuai dengan kondisi dan situasi kegiatan pembelajaran yang akan dihadapi (Efi Yulia, 2018).

Oleh karena itu, lembar kerja peserta didik (LKPD) dapat mempengaruhi hasil belajar peserta didik. Hasil belajar adalah perubahan tingkah laku pada diri seseorang setelah belajar, misalnya dari tidak tahu menjadi tahu, dan dari tidak mengerti menjadi mengerti. Hasil belajar dilambangkan dalam bentuk angka (nilai) sehingga mencerminkan keberhasilan belajar atau prestasi peserta didik dalam periode tertentu. Berdasarkan uraian di atas, hasil belajar merupakan hasil yang diperoleh dari hasil setelah proses terjadinya pembelajaran. (Yulidar, 2018) Hasil belajar adalah kemampuan yang dimiliki siswa setelah ia mengalami pengalaman belajarnya. Sementara itu, hasil belajar merupakan tingkat penguasaan suatu pengetahuan yang dicapai oleh siswa dalam mengikuti program belajar mengajar sesuai dengan tujuan yang ditetapkan (Tahar, I. E. 2016). Hasil belajar merupakan suatu bentuk yang diperoleh dari adanya proses belajar. Ketika proses belajar itu dilakukan maka pada akhirnya rangkain proses tersebut, dapat menghasilkan suatu bentuk perubahan yang nampak pada diri siswa sebagai hasil belajar. Belajar merupakan hasil dari suatu interaksi belajar 
dan tindak mengajar sehingga pengertian hasil belajar merupakan berakhirnya puncak proses belajar. (Rischa Awal Sari, 2017) Dalam hal adalah hasil belajar IPS yang dipengaruhi oleh LKPD. Ilmu Pengetahuan Sosial merupakan (IPS) merupakan salah satu mata pelajaran yang diberikan di tingkat SD. IPS mengkaji seperangkat peristiwa, fakta, konsep dan generalisasi yang berkaitan dengan isu sosial. Ilmu Pengetahuan Sosial adalah program pendidikan yang mengintegrasikan secara interdisiplin konsep ilmu-ilmu sosial dan humaniora (Ayu Febriana, 2011). Ilmu Pengetahuan Sosial (IPS) merupakan salah satu mata pelajaran di SD dirancang untuk mengembangkan pengetahuan, pemahaman, dan kemampuan analisis terhadap kondisi sosial masyarakat dalam memasuki kehidupan bermasyarakat yang dinamis. Mata pelajaran IPS disusun secara sistematis, komprehensif, dan terpadu dalam proses pembelajaran menuju kedewasaan dan keberhasilan dalam kehidupan di masyarakat. (Dwi Indah Rahayuningsih 1, Mustaji 2, W. T. S. 3. 2018) Oleh karena itu diharapkan LKPD dapat membawa perubahan bagi hasil belajar peserta didik, karena LKPD dibuat semenarik mungkin agar hasil belajar peserta didik dapat tercapai sesuai keinginan. Serta LKPD itu dipahami atau materi yang dijelaskan dan dituangkan ke LKPD dapat mempengaruhi hasil belajar.

Namun berdasarkan kondisi yang peneliti temukan dibeberapa lokasi kabupaten Raja Ampat khususnya di SD YPK Getsemani Warwanai pada saat peneliti melakukan observasi disaat magang 3 yang dilaksanakan 60 hari diperoleh bahwa keterampilan guru dalam membuat LKPD masih sangat monoton, dalam hal ini yang peneliti melihat bahwa guru sudah mengetahui cara pembuatan LKPD tetapi belum memahami kemampuan peserta didik dalam memahami LKPD yang dibuat, dan kurang kreatif dalam membuat atau merancang LKPD yang menarik. LKPD yang dibuat kurang menarik akan berdampak pada hasil belajar peserta didik dalam pembelajaran IPS menjadi rendah, peserta didik tidak ada semangat untuk mengerjakan LKPD yang diberikan guru karena LKPD yang diberikan guru hanya berisi tulisan, itu sangat membuat peserta didik bosan atau malas untuk mengerjakan LKPD, sehingga peserta didik hanya mengisi LKPD sesuai keinginan mereka tanpa membaca dan mencari jawaban yang tepat dan benar, itu sangat berpengaruh terhadap hasil belajar peserta didik. Oleh karena itu keterampilan seorang guru dalam menyusun LKPD merupakan salah satu hal yang perlu dilakukan agar dapat menyusun LKPD yang menarik sehingga dapat merubah kebiasaan peserta didik yang bosan atau jenuh pada saat mengerjakan lebih semangat dan teliti dalam memahami soal dan mencari jawaban LKPD dapat berpengaruh pada hasil belajar peserta didik lebih khususnya pada pelajaran IPS.

Tujuan dari penelitian ini adalah untuk mengetahui pengaruh lembar kerja peserta didik (LKPD) terhadap hasil belajar IPS siswa kelas IV SD YPK Getsemani Warwanai. (Ghullam Hamdu, L. A. 2011) Belajar adalah serangkaian kegiatan jiwa raga untuk memperoleh suatu perubahan tingkah laku sebagai hasil dari pengalaman individu dalam interaksi dengan lingkungannya menyangkut kognitif, afektif, dan psikomotorik. Dalam belajar, siswa mengalami sendiri proses dari tidak tahu menjadi tahu. (Yunani, 2015) Hasil belajar adalah suatu penilaian akhir dari proses dan pengenalan yang telah dilakukan berulangulang, serta akan tersimpan dalam jangka waktu lama atau bahkan tidak akan hilang 
selama-lamanya karena hasil belajar turut serta dalam membentuk pribadi individu yang selalu ingin mencapai hasil yang lebih baik lagi sehingga akan merubah cara berpikir serta menghasilkan perilaku yang lebih baik. (Muhammad Iqbal, 2017) Lembar Kerja Peserta Didik (LKPD) adalah lembaran-lembaran berisi tugas yang harus dikerjakan oleh peserta didik dalam kegiatan pembelajaran yang disertai petunjuk atau langkah-langkah untuk menyelesaikan suatu tugas yang memiliki kompetensi dasar yang akan dicapai. Suatu tugas yang diperintahkan dalam lembar kerja harus jelas Kompetensi Dasar (KD) yang akan dicapainya. Keuntungan adanya lembar kerja adalah bagi guru, memudahkan guru dalam melaksanakan pembelajaran, sedangkan bagi siswa akan belajar secara mandiri dan belajar memahami dan menjalankan suatu tugas tertulis.

LKPD biasanya berisikan petunjuk bagi siswa untuk melakukan kegiatan. Ini bertujuan untuk menuntun siswa melakukan kegiatan aktif selama proses pembelajaran. Lembar kegiatan biasanya berupa petunjuk, langkah-langkah untuk menyelesaikan suatu tugas sesuai dengan KD yang akan dicapai. (Krisno Prastyo Wibowo, 2015)

\section{METODE PENELITIAN}

Penelitian ini termasuk jenis penelitian kuantitatif dengan metode eksperimen. Penelitian ini dilaksanakan di SD SD YPK Getsemani Warwanai kelas IV. populasi dalam penelitian ini adalah seluruh siswa kelas IV SD YPK Getsemani Warwanai yang berjumlah 22 siswa. Dalam penelitian ini sampel yang akan diambil adalah siswa kelas IV SD SD YPK Getsemani Warwanai yang berjumlah 22 orang yang terdiri dari 13 siswa laki-laki dan 9 siswa perempuan. Instrument dalam penelitian ini berupa lembar observasi, tes dan dokumentasi. Tekni analisis data penelitian ini menggunakan uji normalitas, homogenitas, N-Gain, dan uji hipotesis.

\section{HASIL DAN PEMBAHASAN}

Penerapan atau penggunaan instrumen lembar observasi aktivitas guru dimaksudkan untuk mendapatkan data aktivitas guru dalam proses pembelajaran yang menggunakan media LKPD, berdasarkan hasil validasi lembar observasi aktivitas guru oleh professional judgment mendapatkan skor 38 . Berdasarkan kriteria penilaian validasi berada pada rentang nilai $30 \leq \mathrm{x}<39$ dengan kategori nilai baik. Jadi kesimpulannya instrumen lembar observasi aktivitas guru dapat digunakan dengan sedikit revisi. Sedangkan penerapan instrumen lembar observasi aktivitas siswa dimaksudkan untuk mendapatkan data aktivitas siswa selama mengikuti pembelajaran yang menggunakan media LKPD, berdasarkan hasil validasi lembar observasi aktivitas siswa oleh professional judgment mendapatkan skor 45 . Berdasarkan kriteria penilaian validasi berada pada rentang nilai $39 \leq \mathrm{x}<48$ dengan kategori nilai sangat baik. Jadi kesimpulannya instrumen lembar observasi aktivitas siswa dapat digunakan tanpa revisi.

Selanjutnya peneliti juga menvalidasi instrumen tes hasil belajar, dengan tujuan agar instrumen tes hasil belajar layak atau valid digunakan pada saat penelitian, berdasarkan hasil validasi oleh professional judgment untuk tes hasil belajar mendapatkan skor 62. Berdasarkan kriteria penilaian validasi berada pada rentang nilai $39 \leq \mathrm{x}<48$ dengan kategori nilai sangat baik. Jadi kesimpulannya instrumen tes hasil belajar dapat digunakan tanpa revisi.

Selain menvalidasi dua instrumen penelitian diatas, peneliti juga melakukan validasi terhadap perangkat pembelajaran 
yakni RPP dan LKPD. Tujuan validasi RPP ini dimaksudkan agar dapat mengetahui apakah materi pembelajaran disekolah yang sedang berlangsung sesuai dengan materi pembelajaran yang akan diteliti oleh peneliti. Berdasarkan hasil validasi RPP oleh professional judgment mendapatkan skor 47. Dalam kriteria penilaian validasi berada pada rentang nilai $39 \leq \mathrm{x}<48$ dengan kategori nilai sangat baik, sehingga disimpulkan RPP dapat digunakan tanpa revisi. Sedangkan validasi LKPD dimaksudkan agar proses pembelajaran sesuai dengan langkah-langkah pembelajaran dalam LKPD dan sajian LKPD sesuai dengan RPP. Berdasarkan hasil validasi LKPD oleh professional judgment mendapatkan skor 40. Dalam kriteria penilaian validasi berada pada rentang nilai $39 \leq \mathrm{x}<48$ dengan kategori nilai sangat baik, sehingga dapat disimpulkan LKPD dapat digunakan tanpa revisi. Berdasarkan penilaian dari semua hasil validasi instrumen dan perangkat pembelajaran oleh professional judgment disimpulkan bahwa instrumen penelitian ini dinyatakan valid dan layak digunakan dengan kategori baik.

Pengujian reliabilitas instrumen diperoleh hasil Cronbach's Alpha untuk instrumen soal pre test sebesar 0,717. Dengan demikian instrumen soal Pre test tersebut telah memenuhi syarat reliabel. Perhitungan uji reliabilitas terhadap instrumen soal post test dengan menggunakan Program IBM SPSS Statistics Versi 21.0, dengan kriteria jika nilai Alpha Cronbach $\geq 0,60$ dikatakan reliabel, diperoleh hasil Cronbach's Alpha untuk instrumen soal post test sebesar 0,619. Dengan demikian instrumen soal post test tersebut telah memenuhi syarat reliable.

Data hasil belajar kelas kontrol dan kelas Eksperiman yang diperoleh dapat dilihat pada tabel 6 hasil belajar awal dan akhir (pre test dan post test) sebagai berikut;

Tabel 1. Hasil Belajar pre test dan post test kelas Kontrol dan Kelas Eksperimen

\begin{tabular}{|c|c|c|c|}
\hline \multirow{2}{*}{ No. } & \multirow[t]{2}{*}{ Nama Siswa } & \multicolumn{2}{|c|}{ Kelompok Kontrol } \\
\hline & & Pre Test & Post Test \\
\hline 1. & AS & 40 & 75 \\
\hline 2. & DKS & 45 & 65 \\
\hline 3. & DS & 60 & 90 \\
\hline 4. & $\mathrm{DM}$ & 55 & 80 \\
\hline 5. & MS & 40 & 85 \\
\hline 6. & MIS & 55 & 85 \\
\hline 7. & NS & 55 & 85 \\
\hline 8. & OS & 65 & 80 \\
\hline 9. & PU & 55 & 80 \\
\hline 10. & YGS & 50 & 75 \\
\hline \multirow[t]{5}{*}{11.} & YR & 60 & 80 \\
\hline & Jumlah & 580 & 880 \\
\hline & Rata-Rata & 52,72 & 80,00 \\
\hline & Nilai Terendah & 40 & 65 \\
\hline & Nilai Tertinggi & 65 & 90 \\
\hline
\end{tabular}

Berdasarkan tabel 1 menunjukkan

\begin{tabular}{|c|c|c|c|}
\hline \multirow[t]{2}{*}{ No. } & \multirow[t]{2}{*}{ Nama Siswa } & \multicolumn{2}{|c|}{ Kelompok Eksperimen } \\
\hline & & Pre Test & Post Test \\
\hline 1. & FHS & 75 & 95 \\
\hline 2. & KS & 55 & 85 \\
\hline 3. & AW & 60 & 80 \\
\hline 4. & BS & 55 & 90 \\
\hline 5. & RS & 60 & 85 \\
\hline 6. & SFF & 60 & 95 \\
\hline 7. & GSS & 55 & 90 \\
\hline 8. & AS & 55 & 90 \\
\hline 9. & ALS & 65 & 95 \\
\hline 10. & DM & 45 & 85 \\
\hline 11. & GS & 50 & 90 \\
\hline & Jumlah & 635 & 980 \\
\hline & Rata-Rata & 57,73 & 89,09 \\
\hline & Nilai Terendah & 45 & 80 \\
\hline & Nilai Ter & 75 & 95 \\
\hline
\end{tabular}

dengan rata-rata 52,72, nilai tertinggi 65, dan bahwa data kelas kontrol diperoleh hasil nilai terendah 40. Sedangkan pada hasil belajar pre test diperoleh jumlah nilai 580, 
dengan rata-rata 80,00 , nilai tertinggi 90 , dan nilai terendah 65. Sedangkan pada kelas eksperimen data hasil belajar pre test diperoleh jumlah nilai 635 , dengan rata-rata 57,72 , nilai tertinggi 75 , dan nilai terendah 45. Sedangkan pada hasil belajar post test diperoleh jumlah nilai 980, dengan rata-rata 89,09 , nilai tertinggi 95 , dan nilai terendah 80. Setelah diperoleh data instrumen penelitian lembar observasi dan instrumen tes hasil belajar, maka langkah selanjutnya adalah peneliti menganalisis data.

\section{Tahap Deskriptif Data}

Deskriptif data hasil penelitian meliputi data pre test kelompok eksperimen, data post test kelompok eksperimen, data pre test kelompok kontrol dan data post test kelompok kontrol. Nilai pre test adalah skor awal hasil belajar siswa, sedangkan nilai post test adalah skor akhir hasil belajar siswa. Untuk mengetahui pengaruh model pembelajaran yang digunakan, dapat dilihat dari mean (nilai rata-rata) dan modus (nilai yang sering muncul) hasil belajar.

Hasil pre test kelompok kontrol yang menggunakan pembelajaran yang biasa digunakan guru dengan jumlah subjek adalah 11 siswa. Hasil belajar pre test kelompok kontrol diperoleh modus adalah 55. Adapun mean pre test kelompok kontrol adalah 52,73. Sedangkan Hasil belajar post test kelompok kontrol diperoleh modus adalah 80 . Adapun mean post test kelompok kontrol adalah 80,00 .

Hasil pre test kelompok eksperimen yang menggunakan pembelajaran yang biasa digunakan oleh guru dengan jumlah subjek adalah 11 siswa. Hasil belajar pre test kelompok eksperimen diperoleh modus adalah 55. Adapun mean pre test kelompok eksperimen adalah 57,73. Sedangkan hasil belajar post test kelompok eksperimen diperoleh modus adalah 90. Adapun mean post test kelompok eksperimen adalah 89,09.
Setelah diperoleh nilai deskriptif data penelitian meliputi data pre test kelompok eksperimen, data post test kelompok eksperimen, data pre test kelompok kontrol dan data post test kelompok kontrol, maka langkah selanjutnya adalah peneliti menganalisis uji prasyarat analisis data.

Uji normalitas digunakan untuk mengetahui apakah data yang diperoleh dari masing-masing variabel berdistribusi normal atau tidak. Perhitungan uji normalitas menggunakan rumus Lilliefors dengan taraf signifikan $5 \%$. Seluruh proses perhitungan dilakukan dengan bantuan komputer program SPSS versi 21.0 for windows. Uji normalitas ini dilakukan terhadap skor pre test dan post test siswa, baik kelompok eksperimen maupun kelompok kontrol. Kriteria yang digunakan adalah jika hasil $\mathrm{p}>0,05$ maka distribusi frekuensi tersebut normal, sebaliknya jika hasil $\mathrm{p}<0,05$ maka distribusi frekuensi tidak normal.

Berdasarkan data dari tabel, dapat diperoleh hasil bahwa nilai Lillieforspada pre test kelompok kontrol 0,246 dengan Sig 0,062 dan nilai Lillieforspada post test kelompok kontrol 0,227 dengan Sig 0,117. Nilai Lilliefors pada pre test kelompok eksperimen 0,204 dengan Sig 0,200 dan nilai Lillieforspada post test kelompok eksperimen 0,210 dengan Sig 0,191. Dari data tersebut dapat dilihat bahwa Asymp Sig (2-tailed) distribusi data yang diperoleh lebih besar dari hasil alpha 0,05. Dapat disimpulkan bahwa Asymp Sig (2-tailed) distribusi data pre test dan post test pada masing-masing variabel normal sehingga dapat digunakan untuk uji statistik parametrik.

Uji homogenitas digunakan untuk mengetahui apakah sampel yang diambil memiliki varian yang sama atau tidak menunjukkan perbedaan yang signifikan satu sama lain. Uji homogenitas dalam penelitian 
ini menggunakan uji levene test. Seluruh proses perhitungan dilakukan dengan bantuan komputer program SPSS versi 21.0 for windows. Kriteria yang digunakan yaitu dari data hasil penelitian yang dikatakan homogen apabila hasil levene test lebih besar dari hasil alpha yaitu 0,05 . Berikut ini rangkuman hasil uji homogenitas data dari hasil belajar siswa pada kelompok kontrol dan kelompok eksperimen.

Berdasarkan data dari tabel, dapat diperoleh hasil bahwa nilai Levene pada pre test kelompok kontrol-eksperimen 0,163 dengan Asymp Sig (2-tailed) 0,690 dan nilai Levene pada post test kelompok kontroleksperimen 0,162 dengan Asymp Sig (2tailed) 0,692. Nilai Levene pada pre testpost test kelompok kontrol 1,025 dengan Asymp Sig (2-tailed) 0,323 dan nilai Levene pada pre test-post test kelompok eksperimen 1,084 dengan Asymp Sig (2-tailed) 0,310. Dari data tersebut dapat dilihat bahwa Asymp Sig (2-tailed) distribusi data yang diperoleh lebih besar dari hasil alpha 0,05. Dapat disimpulkan bahwa Asymp Sig (2tailed) distribusi data pre test dan post test pada kelompok kontrol-eksperimen homogen, distribusi data pre test dan post test pada kelompok kontrol homogen, dan distribusi data pre test dan post test kelompok eksperimen homogen. Dengan demikian penelitian ini layak untuk dilanjutkan.

\section{Uji Hipotesis}

Uji hipotesis dilakukan setelah semua data dari hasil penelitian terkumpul. Tujuan dari uji Paired T-test untuk menguji apakah lembar kerja peserta didik (LKPD) memiliki hasil belajar yang lebih baik terhadap hasil belajar siswa kelas IV SD YPK Getsemani Warwanai dibanding pembelajaran yang digunakan guru selama ini. Secara teknis proses perhitungan dilakukan dengan bantuan komputer program SPSS versi 21.0 for windows.

Kriteria yang digunakan adalah apabila nilai thitung $>$ ttabel atau sig $<0,05$ maka H1diterima dan $\mathrm{H} 0$ ditolak yang berarti lembar kerja peserta didik (LKPD) memiliki hasil yang lebih baik terhadap hasil belajar IPS siswa kelas IV SD YPK Getsemani Warwanai dibanding pembelajaran yang digunakan guru selama ini, sedangkan apabila nilai thitung $<$ ttabel atau sig $>0,05$ maka $\mathrm{H} 1$ ditolak dan $\mathrm{H} 0$ diterima yang berarti berarti lembar kerja peserta didik (LKPD) tidak memiliki hasil yang lebih baik terhadap hasil belajar IPS siswa kelas IV SD YPK Getsemani Warwanai dibanding pembelajaran yang digunakan guru selama ini. Hasil analisis selengkapnya dapat dilihatpada tabel 2 berikut ini.

Tabel 2. Hasil Uji Paired T-test Kelompok Eksperimen-Kontrol

\begin{tabular}{|c|c|c|c|c|}
\hline \multicolumn{5}{|c|}{ Paired Samples Test } \\
\hline & & Paired & df & Sig. (2- \\
\hline & & Differences & & tailed) \\
\hline \multicolumn{5}{|c|}{ Means } \\
\hline & Kontrol & -27.273 & -11.06610 & .000 \\
\hline Paired & Eksperime & -31.364 & -14.64410 & .000 \\
\hline
\end{tabular}

Berdasarkan tabel 2. hasil analisis uji Paired T-test menunjukkan bahwa nilai thitung dari pre test-post test kelompok kontrol bernilai negatif yaitu sebesar -11,066 dan thitung dari pre test-post test kelompok eksperimen bernilai negatif yaitu sebesar 14,644. thitung bernilai negatif disebabkan karena nilai rata-rata hasil belajar Pre test lebih rendahdari pada nilai rata-rata Post test. Dalam Konteks kasus seperti ini maka nilai thitung negatif dapat bermakna positif. Sehingga nilai thitung dari pre test-post test kelompok kontrol menjadi 11,066 dan nilai thitung dari pre test-post test kelompok eksperimen menjadi 14,644.

Selanjunya adalah tahap mencari ttabel, dimana ttabel dicari berdasarkan nilai df 
(degree of freedom atau derajad kebebasan) dan nilai signifikansi $(\propto / 2)$. Dari data di atas diketahui nilai df adalah sebesar 10 dan nilai $0,05 / 2$ sama dengan 0,025 . Nilai ini kita gunakan sebagai dasar acuan dalam mencari nilai ttabel pada distribusi nilai ttabel statistik. Maka ketemu nilai ttabel adalah sebesar 2,228.

Dari data tersebut terlihat nilai thitung $>$ ttabel pada kedua kelompok, namun thitung pada kelompok eksperimen lebih besar dari thitung kelompok kontrol sehingga $\mathrm{H}_{1}$ diterima dan $\mathrm{H}_{0}$ ditolak. Artinya lembar kerja peserta didik (LKPD) memiliki hasil yang lebih baik terhadap hasil belajar IPS siswa kelas IV SD Getsemani Warwanai dibanding pembelajaran yang digunakan guru selama ini. Jadi dapat disimpulkan bahwa terdapat hasil yang lebih baik pada kelompok eksperimen yang menggunakan lembar kerja peserta didik (LKPD) dibandingkan dengan kelompok kontrol yang menggunakan pembelajaran yang biasa digunakan guru.

Hasil analisa kelas control bahwa selisih antara nilai pre test dan post test kelompok kontrol menghasilkan N-Gain. Terdapat 2 peserta didik yang memperoleh kategori tinggi, terdapat 9 peserta didik yang memperoleh kategori sedang dan peserta didik di kategori rendah tidak ada. Sedangkan untuk rata-rata nilai pre test kelompok kontrol sebesar 52,73 dan rata rata nilai post test kontrol sebesar 80,00 dengan perolehan rata-rata $\mathrm{N}-$ Gain skor sebesar 0,57 dan masuk dalam kategori sedang. Sedangkan hasil analisa kelas eksperimen bahwa selisih antara nilai pre test dan post test kelompok eksperimen menghasilkan $\mathrm{N}$ Gain. Terdapat 8 peserta didik yang memperoleh kategori tinggi, terdapat 3 peserta didik yang memperoleh kategori sedang dan peserta didik di kategori rendah tidak ada. Sedangkan untuk rata-rata nilai pre test kelompok ekperimen sebesar 57,73 dan rata rata nilai post test eksperimen sebesar 89,09 dengan perolehan rata-rata N-Gain skor sebesar 0,74 dan masuk dalam kategori tinggi.

Perbedaan analisa dari kedua kelas bahwa selisih antara nilai post test kelompok kontrol dan post test kelompok eksperimen menghasilkan N-Gain. Terdapat 3 peserta didik yang memperoleh kategori tinggi, terdapat 7 peserta didik yang memperoleh kategori sedang dan terdapat 1 peserta didik di kategori rendah. Sedangkan untuk rata-rata nilai post test kelompok kontrol sebesar 80,00 dan rata rata nilai post test eksperimen sebesar 89,09 dengan perolehan rata-rata $\mathrm{N}$ Gain skor sebesar 0,54 dan masuk dalam kategori sedang dan jika dari nilai rata-rata terdapat perbedaan antara nilai post test kelompok kontrol dan nilai post test kelompok eksperimen. Secara detail dapat dilihat pada tabel 3 .

Tabel 3. Data Indeks Gain

\begin{tabular}{|c|c|c|c|}
\hline Kelas & Siswa & Rata-Rata & $\begin{array}{l}\text { Persen } \\
\%\end{array}$ \\
\hline Kontrol & 11 & 0,57 & $57 \%$ \\
\hline Eksperimen & 11 & 0,74 & $74 \%$ \\
\hline $\begin{array}{ll}\text { Posttest } & \text { Kontrol } \\
\text { dan } & \text { posttest } \\
\text { Eksperimen }\end{array}$ & 11 & 0,54 & $55 \%$ \\
\hline
\end{tabular}

Berdasarkan tabel 3 di atas, terlihat hasil perhitungan N-Gain memiliki perbedaan nilai rata-rata antara pre test-post test kelas kontrol dan pre test-post test kelas eksperimen dan juga post test kelas kontrol dan post test kelas eksperimen. N-Gain dilakukan untuk melihat tinggi rendahnya peningkatan hasil belajar siswa sebelum dan sesudah pembelajaran menggunakan LKPD dalam pembelajaran. Nilai N-Gain hasil belajar kelas kontrol tanpa menggunakan LKPD masih didominasi oleh kategori sedang $(0,30 \leq$ nilai $\mathrm{N}-$ Gain $\leq 0,70)$ rata-rata 0,57 dan $57 \%$ hal tersebut dikarenakan siswa 
masih belum pernah menggunakan pembelajaran dengan LKPD sedangkan kelas eksperimen dengan menggunakan LKPD menunjukan peningkatan dikategori tinggi (nilai $\mathrm{N}-$ Gain > 0,70) nilai $\mathrm{N}-$ Gain rata-rata kelas eksperimen yaitu 0,74 dan $74 \%$ maka dapat dinyatakan LKPD mempunyai pengaruh dalam hasil belajar ips siswa terlihat peningkatan hasil belajar dari yang sedang ke tinggi. Nilai N-Gain hasil belajar post test kelas kontrol dan post test kelas eksperimen masih didominasi oleh kategori sedang $(0,30 \leq$ nilai $\mathrm{N}$-Gain $\leq 0,70)$ ratarata 0,54 dan $54 \%$.

Penelitian tentang pengaruh penggunaan lembar kerja peserta didik (LKPD) terhadap hasil belajar IPS siswa kelas IV SD YPK Getsemani Warwanai membuktikan ada kinerja yang lebih baik.

\section{KESIMPULAN}

Berdasarkan hasil penelitian dapat diperoleh bahwa: 1) terdapat pengaruh lembar kerja peserta didik (LKPD) terhadap hasil belajar IPS siswa kelas IV SD YPK Getsemani Warwanai. Dengan hasil analisis data nilai yaitu thitung $>$ ttabel $(14,644>2,228)$, dengan besarnya taraf signifikansi 0,05 yakni $(0,000<0,05)$ maka hipotesis H1 diterima H0 ditolak. Dapat disimpulkan dalam pembelajaran menggunakan lembar kerja peserta didik (LKPD) pada siswa kelas IV SD YPK Getsemani Warwanai terbukti memberi kinerja yang lebih baik bagi peningkatan hasil belajar IPS siswa. 2) hasil Uji N-Gain melihat pengaruh yang diberikan lembar kerja peserta didik (LKPD) terhadap hasil belajar IPS siswa dari kelas eksperimen nilai rata-rata $\mathrm{N}$-gain skor yaitu 0,74 dan $74 \%$ dimana nilai tersebut masuk dalam kategori tinggi. 3) Lembar Kerja Peserta Didik (LKPD) berpengaruh terhadap hasil belajar
IPS.

\section{DAFTAR RUJUKAN}

Anggraeni, D. (2011). Peningkatan kualitas pembelajaran IPS melalui model pembelajaran kooperatif tipe Course Review Horay pada siswa kelas IV SD Negeri Sekaran 01 Semarang (Doctoral dissertation, Universitas Negeri Semarang).

Ayu Al Khaerunisa. (2012). Meningkatkan Minat Belajar Siswa Dalam Membuat Hiasan Pada Busana (Embroidery) Melalui Model Pembelajaran Kooperatif Tipe Numbered Head Together Di SMK Karya Rini Yogyakarta.

Ayu Febriana. (2011). Penerapan Model Pembelajaran Kooperatif Tipe Make A Match Untuk Meningkatkan Kualitas Pembelajaran Ips Siswa Kelas V SDN Kalibanteng Kidul 01 Kota Semarang, 1(2).

Dian Vita Sari. (2019). Pengembangan Lembar Kerja Peserta Didik (Lkpd) Pada Mata Pelajaran IPS KELAS V Tahun Ajaran 2018/2019.

Dwi Indah Rahayuningsih 1, Mustaji 2, W. T. S. 3. (2018). Pengembangan Lembar Kerja Peserta Didik (Lkpd) Dengan Pendekatan Saintifik Untuk Meningkatkan Hasil Belajar Mata Pelajaran IPS Bagi Siswa Kelas IV Sekolah Dasar,4(2).

Efi Yulia. (2018). Meningkatkan Minat Belajar Siswa Melalui Penggunaan Lembar Kerja Peserta Didik (LKPD) Pada Pembelajaran Sejarah Kelas XII IPS DI SMA Yadika Natar Tahun 2018.

Ghullam Hamdu, L. A. (2011). Pengaruh Motivasi Belajar Siswa Terhadap Pestasi Belajar IPA Di Sekolah Dasar, 12(1).

Harisandy, R. (2015). Peningkatan Hasil Belajar Siswa Keas XI pada Mata Pelajaran Pengendali Daya Tegangan Rendah SMK 1 Sedayu melalui Model Kooperatif Tipe GI (Group 
Investigation).

Kiswoyowati, A. (2011). Pengaruh motivasi belajar dan kegiatan belajar siswa terhadap kecakapan hidup siswa.Portal Jurnal Universitas Pendidikan Indonesia, 2(1), 12-16.

Krisno Prastyo Wibowo, M. (2015). Penerapan Model Make A Match Berbantuan Media Untuk Meningkatan Motivasi Dan Hasil Belajar IPS, 2(2).

Muhammad Iqbal. (2017). Pengembangan Lembar Kerja Peserta Didik (LKPD) Dengan Pendekatan Kotekstual Ditinjau Dari Pemahaman Konsep Dan Disposisi Matematis.

Najib, A. (2012). Pengaruh pendidikan karakter terhadap prestasi belajar siswa,9(20).

Nur'Ainun. (2017). Pengaruh Kebiasaan Belajar Siswa Terhadap Hasil Belajar Akidah Akhlak Siswa Kelas VII MTS Yayasan Pendidikan Pesantren Rahmat Hamparan Perak.

Resmiyati, E. (2016). Penggunaan Alat Peraga untuk Meningkatkan Aktivitas dan Hasil Belajar Siswi pada Pelajaran Matematika Kelas IV SD Negeri 9 Metro Pusat.

Rischa Awal Sari. (2017). Pengaruh Penggunaan Lembar Kerja Peserta Didik (LKPD) Pada Pembelajaran PAI Terhadap Hasil Belajar Peserta Didik Di SMP Negeri 4 Takalar Kabupaten Takalar.

Sjukur, S. B., Negeri, S. M. K., Kab, S., \& Bumbu, T. (n.d.). Hasil Belajar Siswa Tingkat SMK The Effects Of Blended Learning On The Learning Abstract: The Effects of Blended Learning on the Learning Motivation and Achievement Students in,2(November 2012).

Sugiyono. (2015). Metode Penelitian Kuantitatif, Kualitatif dan $R \& D$.

Solekhah, I. M., \& Hadi, S. (2014). Pengaruh Fasilitas Belajar dan Lingkungan
Keluarga terhadap Hasil Belajar IPS Terpadu Melalui Motivasi Belajar SMP Negeri 1 Ambarawa. Economic Education Analysis Journal, 3(2), 372378.

Tahar, I. E. (2016). Hubungan kemandirian belajar dan hasil belajar pada pendidikan jarak jauh, 7(2).

Umbaryati. (2013). Pentingnya LKPD pada Pendekatan Scientific Pembelajaran Matematika, 2(1).

Wardana, I., Banggali, T., \& Husain, H. (2017). Penerapan model pembelajaran kooperatif tipe student team achivement division (STAD) untuk meningkatkan hasil belajar siswa kelas XI IPA Avogadro SMA Negeri 2 Pangkajene (Studi pada Materi Asam Basa). Chemica: Jurnal Ilmiah Kimia dan Pendidikan Kimia, 18(1), 76-84.

Wiwik Sulistiana Dewi. (2017). Penerapan Model Pembelajaran Hands On Mathematics Berbantuan LKPD Yang Terintegrasi Pada Simbol-Simbol Keislaman Terhadap Kemampuan Berpikir Kritis Matematis Peserta Didik.

Yesi Budiarti. (2015). Pengembangan Kemampuan Kreativitas Dalam Pembelajaran Ips, 3(1).

Yuliastuti, H. (2014). Meningkatkan hasil belajar matematika pada materi penjumlahan dan pengurangan bilangan bulat dengan model pembelajaran kooperatif tipe stad.

Yulidar. (2018). Pengaruh LKPD Berbasis Komik Didaktis Terhadap Hasil Belajar Peserta Didik Kelas VIII MTSN 6 Aceh Besar Pada Materi Gerak Lurus.

Yunani. (2015). Upaya Meningkatan Hasil Belajar Siswa pada Mata Pelajaran PAI dalam Mengenal Malaikat dan Tugasnya Melalui Metode Make a Match di Kelas IV SD Negeri 103 Palembang. 